\title{
咽喉頭異常感を主訴とした甲状腺癌症例
}

\author{
矢野原邦生 ${ }^{12}$ - 宮原 幸則 ${ }^{12}$ - 加藤 昭彦1) \\ 宮木 良生 ${ }^{2)}$ 山田 弘之 ${ }^{3)}$
}

\section{Thyroid Cancer in the Patients with Throat Paresthesia}

\author{
Kunio Yanohara, Yukinori Miyahara, \\ Akihiko Kato and Yoshio Miyaki \\ (Yamada Red Cross Hospital) \\ Hiroyuki Yamada \\ (Mie University)
}

\begin{abstract}
Increasing numbers of patients complain of paresthesia in the throat. Generally they are worried about cancer, and it is our role to rule out malignant disease. In this paper we stress the importance of ultrasonographic examination of the thyroid in patients with paresthesia in the throat. Ultrasonographic examinations of the thyroid were performed in 536 patients with paresthesia and 7 cases of thyroid cancer $(1.3 \%)$ were diagnosed.
\end{abstract}

Key words: thyroid cancer, throat paresthesia, ultrasonographic examination

はじめに

咽喉頭異常感を訴える患者を問診していると， その多くが癌に代表される悪性疾患に対して 強い不安感を抱いているのがわかる. 従って本 症を扱う場合，患者に癌でないととをいかに納 得させるかが，治療の要点になってくるといっ ても過言ではない，我々が従来本症にたいして ルチン検査として用いてきた下咽頭食道造影法 は，患者を納得させる手段としては有用ではあ ったが，我々の経験に限っていえば本法により 悪性疾患を発見しえたことはなく，また放射線 被爆の点からもルチン㭘査として全症例に施行 することは問題があると考えた ${ }^{122}$. そこで最近
我々は本法をごく限られた症例にのみ用いると ととして，患者を納得させるためのルチン検査 の一つとして甲状腺超音波検査を施行するとと にしている，その結果予想に反して高率に甲状 腺癌を発見し，甲状腺超音波検査の有用性を確 認したので報告する.

\section{対象および方法}

1986年 7 月より 1988年 4 月までの 1 年10力月 間に当科を受診した咽喉頭異常感症例は 536 例 で同期間の新患総数 8360 名の約 $6.4 \%$ あるあ. これらのすべてに甲状腺超音波検査を施行した. 超音波診断装置は，アロカ社製 SSD 280型抒 よび SSD 650 型を用いた。振動子は $5 \mathrm{MHz}$,

1）山田赤十字病院耳鼻咽喉科

2）山田赤十字病院放射線科

3 ）三重大学医学部耳鼻咽喉科学教室 
または $7.5 \mathrm{MHz}$ を用いて水浸法にて観察した.

\section{結果}

甲状腺超音波検査を受けた男性 183 例，女性 353例，計536例中，超音波検査上腫大，内部工 コーの不整を含む何らかの所見を有したもの は，221例 (41.2\%) であり，さらに結節性腫 瘤を有すると診断されたものは149例（27.8\%）

表 1

\begin{tabular}{|c|c|c|c|}
\hline & 男 & 女 & 計 \\
\hline $\begin{array}{l}\text { 咽喉頭知覚異常を主訴と } \\
\text { した当科栄数 }\end{array}$ & 183 & 353 & 536 \\
\hline $\begin{array}{l}\text { 超音波検查にて所見を有 } \\
\text { する症例数 }\end{array}$ & 69 & 152 & $\begin{array}{c}221 \\
(41.2 \%)\end{array}$ \\
\hline 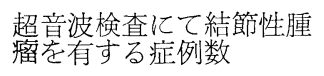 & 37 & 112 & $\begin{array}{c}149 \\
(27.8 \%)\end{array}$ \\
\hline 手術施行症例数 & 2 & 20 & $\left(\begin{array}{c}22 \\
(4.1 \%)\end{array}\right.$ \\
\hline 癌症例数 & 0 & 7 & $\begin{array}{c}7 \\
(1.3 \%)\end{array}$ \\
\hline
\end{tabular}

表 2 超音波所見による分類 (内部エコー・パターン)

（田中 稉，他：1986 ${ }^{3}$ より転载）

\begin{tabular}{ll}
\hline Type I & cyst \\
Type II & regular polyp in cyst \\
Type III & irregular polyp in cyst \\
Type IV & multiple cyst in solid mass \\
Type V & solitary cyst in solid mass \\
Type VI & solid mass
\end{tabular}

であった（表 1 ）。結節性腫瘤の内部エコーの パターン分類は田中らの方法 (表 2$)^{32}$ に従い大 まかに 6 タイプに分類すれば, 癌の多くはタイ プIIIむしくはタプVIに含まれる。さらにタイ プIII，VI に含まれる全例に CT 検査を施行し， 可能な限り aspiration biopsy cytology (ABC) も行なうことにより，手術適応を決定する参考 とした。手術が施行されたのは22例 (4.1\%)で あり，その内 7 例 $(1.3 \%)$ が癌之唁断された (表2).

症例（表 3 ）

手術により癌と確㡣されたものは7 例で，全 例女性であった。

初診時腫瘍を触知できたものは 3 例，触知で きなかったものは 4 例であった。

当然患者は全例共, 初診時自らの甲状腺腫瘍 に気づいてはいない。

超音波検査による内部エコーのパターン分類 では，タイプIII 1 例，タイプVI 5 例で，残る 1 例は腫瘍を触知したにすかかわらず超音波検査 で腫瘍が描出されなかった例である。

$\mathrm{CT}$ 検査では辺縁整なものが 1 例，不整なも のが 5 例であった。

手術術式は峡を含む片葉切除が 4 例，巠全摘 が 1 例, 全摘が 2 例で，所属りンパ節 I から IV 以下の範囲のリンパ節郭清を全例に施行した.

表 3 癌症例一覧

\begin{tabular}{|c|c|c|c|c|c|c|c|}
\hline 症 例 & 年鄰命 - 性 & 超音波所見 & CT 所見 & 術 式 & 組織型 & pTNM & 触診 \\
\hline $\begin{array}{l}\text { No. } 1 \\
\text { T. F. }\end{array}$ & 49 女 & $\begin{array}{l}\text { 右葉 } 7 \times 7 \text { mm } \\
\text { III型 }\end{array}$ & $\operatorname{Mass}(-)$ & $\begin{array}{l}\text { Rt-Hemi } \\
\text { Rt-PND }\end{array}$ & $\mathrm{Pa}-\mathrm{Ca}$ & pT1N1M0 & $(-)$ \\
\hline $\begin{array}{l}\text { No. } 2 \\
\text { C. H. }\end{array}$ & 49 女 & $\begin{array}{l}\text { 左葉 } \\
\text { びま性腫大 }\end{array}$ & $\begin{array}{l}\text { Lt-LD Mass } \\
\text { 辺縁 整 }\end{array}$ & $\begin{array}{l}\text { Lt-Hemi } \\
\text { Lt-PND }\end{array}$ & $\mathrm{Pa}-\mathrm{Ca}$ & pT2N0M0 & $(+)$ \\
\hline $\begin{array}{l}\text { No. } 3 \\
\text { F. T. }\end{array}$ & 65 女 & $\begin{array}{l}\text { 右葉 } 10 \times 10 \mathrm{~mm} \\
\text { Vl型 }\end{array}$ & $\begin{array}{l}\text { Rt-LD Mass } \\
\text { 辺縁 不整 }\end{array}$ & $\begin{array}{l}\text { Total } \\
\text { Rt-PND }\end{array}$ & $\mathrm{Pa}-\mathrm{Ca}$ & pT4N1M0 & $(-)$ \\
\hline $\begin{array}{l}\text { No. } 4 \\
\text { T. T. }\end{array}$ & 36 女 & $\begin{array}{l}\text { 右葉 } 17 \times 12 \mathrm{~mm} \\
\text { V型 }\end{array}$ & $\begin{array}{l}\text { Rt-LD Mass } \\
\text { 辺縁 不整 }\end{array}$ & $\begin{array}{l}\text { Total } \\
\text { Rt-PND }\end{array}$ & $\mathrm{Pa}-\mathrm{Ca}$ & pT4N1M0 & $(-)$ \\
\hline $\begin{array}{l}\text { No. } 5 \\
\text { Y. Y. }\end{array}$ & 43 女 & $\begin{array}{l}\text { 左葉 } 20 \times 20 \mathrm{~mm} \\
\text { VI型 }\end{array}$ & $\begin{array}{l}\text { Lt-HD Mass } \\
\text { 辺縁 不整 }\end{array}$ & $\begin{array}{l}\text { Lt-Hemi } \\
\text { Lt-MND }\end{array}$ & $\mathrm{Pa}-\mathrm{Ca}$ & pT2N1M0 & $(+)$ \\
\hline $\begin{array}{l}\text { No. } 6 \\
\text { T. N. }\end{array}$ & 45 女 & $\begin{array}{l}\text { 右葉 } 12 \times 12 \mathrm{~mm} \\
\text { V型 }\end{array}$ & $\begin{array}{l}\text { Rt-HD Mass } \\
\text { 辺縁 不整 }\end{array}$ & $\begin{array}{l}\text { Rt-Hemi } \\
\text { Rt-PND } \\
\text { RN Section }\end{array}$ & $\mathrm{Pa}-\mathrm{Ca}$ & pT4N0M0 & $(+)$ \\
\hline $\begin{array}{l}\text { No. } 7 \\
\text { T. O. }\end{array}$ & 48 女 & $\begin{array}{l}\text { 右葉 } 10 \times 9 \mathrm{~mm} \\
\text { V型 }\end{array}$ & $\begin{array}{l}\text { Rt-Hetero Mass } \\
\text { 辺縁 不整 }\end{array}$ & $\begin{array}{l}\text { Rt-Subtot } \\
\text { Rt-PND }\end{array}$ & $\mathrm{Pa}-\mathrm{Ca}$ & pT1N0M0 & $(-)$ \\
\hline
\end{tabular}


症例 6 では腫瘍と剝離困難であった反回神経を 切断した。組織型は全例乳頭癌であった。

術後の TNM 分類は $\mathrm{T} 1$ が 2 例, T2 が 2 例, T4 が 3 例であり， 4 例に所属リンパ節転移を 認めた。

\section{考 按}

咽喉頭異常感圭訴える患者の多くは，癌に対 する強い不安感をむっている。乙れらの患者を 扱うに際して，ファイバースコープに代表され る視診のみで異常なしと告げてむ，患者は満足 せず，充分納得が得られない。 そこではじめに 述べた理由で, 従来の下咽頭食道造影検查に代 わるあのとして甲状腺超音波検査をルチン検査 として採用してみた。

その結果536例中 7 例 (1.3\%) という予想以 上の甲状腺癌を発見，治療することができた。

今回我々が発見した 7 例の甲状腺癌が, 咽喉 頭異常感の原因になっていたか否汃という点に ついては本論文の主目的ではなく，対象をとっ た充分な検討が行なえていない，ただ釘本ら の疫学的調査によると, 甲状腺癌の頻度は人口 1000 につき 1.3 であるといわれる. 一方剖検に おける甲状腺癌の頻度は桑田 ${ }^{5)}$ の $1.1 \%$ 力 万矢 川ら6)の13.7\%という高率なものまで報告がみ られる。とれらの数字と, 最近の超音波診断装 置の優れた性能を考えあわせれば，咽喉頭異常 感患者に $1.3 \%$ 頻度で甲状腺癌が発見された ことは決して高率とは言えず，この点において は咽喉頭異常感と甲状腺癌との因果関係は証明 されなかった。

一方今回の甲状腺癌症例の $\mathrm{T}$ 分類をみると, 7 例中 3 例が $\mathrm{T} 4$ 症例亡, 進行例の占める割合 が極めて高い．とくに 2 症例 (No 3, No 4) は前 頸筋に浸潤がみられ，異常感を誘発する原因に なりうると考える.

我々は甲状腺腫瘍の画像診断法のファースト チョイスとして超音波診断を用いているが，耳 鼻咽喉科領域では RI 診断, CT 診断を優先す 万施設屯多い.

しかし，超音波䛦断装置の解像能はきわめて
優れており，図１でみられるようにCT 検査で 描出不能であった直径 $7 \mathrm{~mm}$ の癌が描出可能で ある。また図 2 ，図 3 のように周囲組織との関 係, 特に前頸筋との関係も CT 画像より優れて

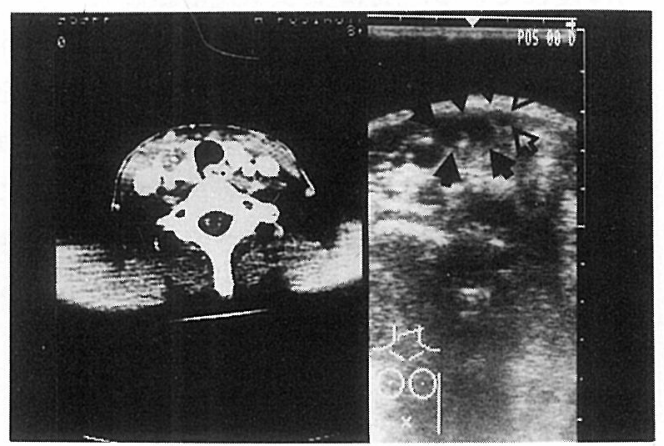

図 1 超音波検査 : 右葉に而型（黒矢印）およびそれ

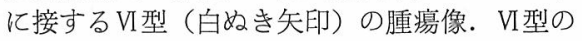
部分が癌.

$\mathrm{CT}$ : 癌の部分は描出されていない。

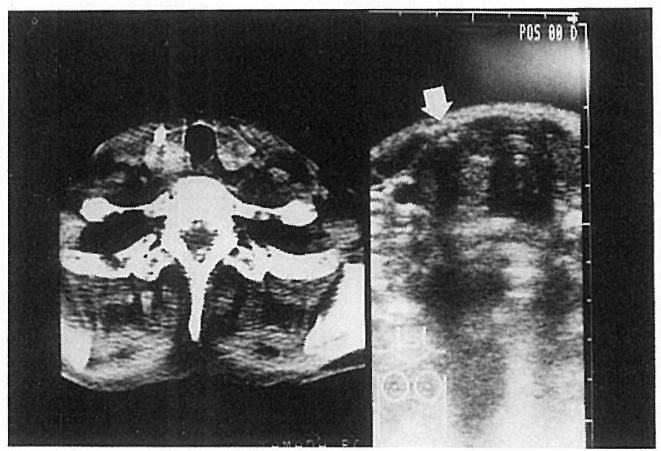

図 2 超音波検査：前頸筋への浸潤が認められ T4 症 例と䛦断できる.

$\mathrm{CT}$ ：前頸筋との関係は明らかでない.

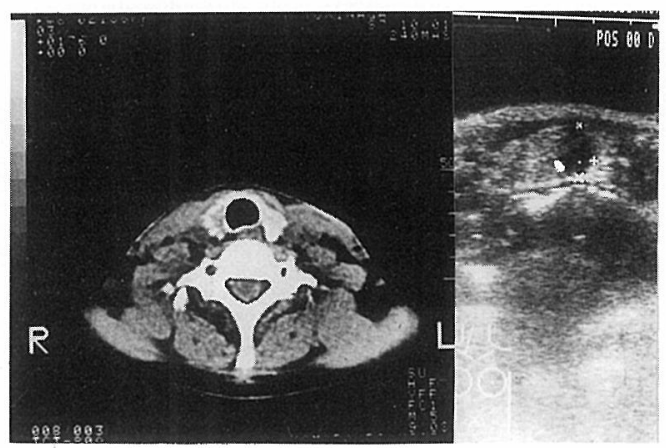

図 3 図 2 之同様 
いる場合も多く, 病期の判定にも有用性が高い. てのように症例によっては部位的䛦断のみなら ず質的診断においても， $\mathrm{CT}$ 検查に比べて劣ら ない。また患者に対する侵襲という面では圧倒 的に優れている. 特に咽喉頭異常感患者に多く 見られるような $10 \mathrm{~mm}$ 前後の腫瘍を日常外 来でスクリーニングする手段としては，触診を 補うあのとしての役割は大きい。ただ，10 mm 前後の腫瘍に対する手術適応を決定するにあた っては過剩治療にならないよう慎重であるべき で，それには超音波診断装置下の $\mathrm{ABC}$ による 䛦断が有力な手助けになると考えている.

\section{参考文献}

1 ）山田弘之, 矢野原邦生, 宮木良生 : 咽喉頭異常感 患者に求ける甲状腺超音波晾断の意義（第 1 報）. 耳喉 59：587〜 591， 1987.
2 ）山田弘之, 矢野原邦生：咽喉頭異常感患者におけ る甲状腺超音波検査の意義. 超昌波医学 $15 ： 273$ $\sim 277,1988$.

3 ) 田中 穣, 田岡大樹, 中川俊一, 他 : 当科におけ る結節性甲状腺腫切除例の検討。日超医論文集 49 : 371 372, 1986.

4 ）釘本 完, 丸地信弘：甲状腺癌の疫学的問題. 臨 床外科 $22 ： 1255 \sim 1260 ， 1967$.

5 ）桑田雪雄：悪性甲状腺腫の研究. 日内分泌誌 42 : 145 156, 1966.

6 ）矢川寛一，高橋信二，村田俊夫，他：潜在性甲状 腺癌の臨床病理学的研究. 日内分泌誌 $43: 825$, 1967.

(原稿受付 : 平成元年 8 月 17 日 原稿採択 : 平成元年 8 月 29 日 別刷請求先 : 矢野原邦生 T516 三重県度会郡御薗村大字高向 810 山田赤十字病院耳鼻咽喉科 